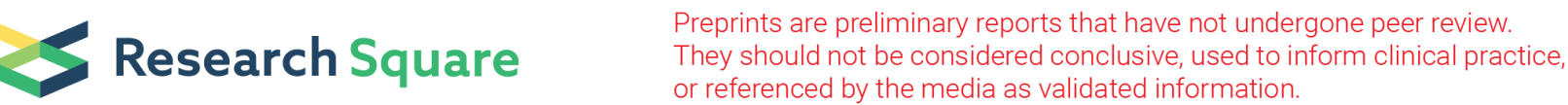

\section{Lipid Profile and Blood Glucose Level of Hypertensive Population in Rural Regions of West China.}

\section{Lihong Fan}

Xi'an Jiaotong University Medical College First Affiliated Hospital

\section{Xiaojing Hu}

Ninth hospital of Xi'an

\section{You Li}

Xi'an Jiaotong University Medical College First Affiliated Hospital

\section{Tiao Bai}

Ninth hospital of Xi'an

\section{Longfei Pan}

Xi'an Jiaotong University Second Affiliated Hospital

\section{Hua Tian}

Xi'an Jiaotong University Second Affiliated Hospital

\section{Yifan Wang}

Xi'an Jiaotong University Medical College First Affiliated Hospital

\section{Qun Lu}

Xi'an Jiaotong University Medical College First Affiliated Hospital

\section{Aiqun $\mathrm{Ma}$}

Xi'an Jiaotong University Medical College First Affiliated Hospital

Hongyan Tian ( $\square$ tianhongyan2020@163.com )

Xi'an Jiaotong University Medical College First Affiliated Hospital https://orcid.org/0000-0001-53469716

\section{Research}

Keywords: dyslipidemia, blood glucose, diet, hypertension, rural regions

Posted Date: December 30th, 2020

DOI: https://doi.org/10.21203/rs.3.rs-136355/v1

License: (c) (i) This work is licensed under a Creative Commons Attribution 4.0 International License. Read Full License 


\section{Abstract}

Background: In rural regions of West China, there was almost no intervention on dyslipidemias and abnormal glucose metabolism of individuals with hypertension because of no literature reporting the lipid profile or blood glucose of these patients. This study was designed to investigate the lipid profile and blood glucose level of the hypertensive population in these regions.

Methods: A cross-sectional community survey was carried out in Xunyi county of Shaanxi province in West China. The study enrolled 1425 hypertensive patients. The lipid profile and blood glucose levels were assessed. Diet and physical activity were also investigated by questionnaire.

Results: $54 \%$ of the population had dyslipidemias. The hypercholesterolemia (hyper-TC) and hypertriglyceridemia (hyper-TG) were the main dyslipidemias (hyper-TC:25\%; hyper-TG: $33 \%$ ). The prevalence of abnormal glucose metabolism was $37 \% .16 \%$ of the population had hyperglycemia. Despite of low-fat intake, the diet was unbalanced by excess salt consumption and seriously insufficient intake of vegetables, fruits and protein.

Conclusion: Dyslipidemias and abnormal glucose metabolism were common in the hypertensive patients in rural areas of West China. They were needed to be invented to reduce the risks of atherosclerotic cardiovascular diseases of hypertensive patients in these regions. Unbalanced diet here may be needed to be modified.

\section{Full Text}

Due to technical limitations, full-text HTML conversion of this manuscript could not be completed. However, the latest manuscript can be downloaded and accessed as a PDF.

\section{Tables}

Table 1 Characters and anthropometric measurement of the studied hypertensive population 


\begin{tabular}{|lll|}
\hline Variables & & \\
\hline Total & & 1425 \\
\hline Gender & Men & $599(42 \%)$ \\
\hline Age(years) & & $826(58 \%)$ \\
\hline Height(cm) & & $62.6 \pm 8.2$ \\
\hline Body weight(kg) & & $158.1 \pm 8.2$ \\
\hline BP*(mmHg) & & $61.1 \pm 10.2$ \\
\hline & SBP & $153 \pm 21$ \\
\hline BMl & DBP & $93 \pm 13$ \\
\hline WC\#(cm) & & $24.4 \pm 3.5$ \\
\hline Obesity & & $83.4 \pm 9.8$ \\
\hline & Overweight by BMI & $535(36 \%)$ \\
\hline Central obesity & & $200(14 \%)$ \\
\hline & Obesity by BMI & $539(38 \%)$ \\
\hline
\end{tabular}

$\mathrm{BP} * \llbracket$ Blood pressure; SBP: Systolic blood pressure; DBP: Diastolic blood pressure; WC $\rrbracket^{\sharp}$ waist circumference

Obesity is determined by $\mathrm{BMI} \geq 28$ according to Chinese BMI cut points. Central obesity is determined by WC $\geq 90 \mathrm{~cm}$ for men and $\geq 85 \mathrm{~cm}$ for women according to Chinese cut points of WC. The prevalence of obesity was only $16 \%$ by BMI, but that of central obesity was $53 \%$ by WC.

Table 2 Lipid profile of the hypertensive patients 


\begin{tabular}{|llll|}
\hline & Total & Men & Women \\
\hline $\mathrm{N}$ & 1425 & 599 & 826 \\
\hline Serum lipid $\ \mathrm{~m} \pm$ SD,mmol/L】 & & \\
\hline TC & $4.60 \pm 0.96$ & $4.39 \pm 0.87$ & $4.75 \pm 1.00$ \\
\hline LDL-c & $2.53 \pm 1.07$ & $2.43 \pm 1.08$ & $2.60 \pm 1.06$ \\
\hline HDL-C & $1.41 \pm 0.40$ & $1.34 \pm 0.34$ & $1.45 \pm 0.44$ \\
\hline TG & $1.60 \pm 1.00$ & $1.46 \pm 0.95$ & $1.69 \pm 1.02$ \\
\hline Patients with & $774(54 \%)$ & $284(47 \%)$ & $490(59 \%)$ \\
\hline dyslipidemias(N, \%) & & & \\
\hline hyper TC & $360(25 \%)$ & $100(17 \%)$ & $260(31 \%)$ \\
\hline hyper LDL-c & $159(11 \%)$ & $46(8 \%)$ & $113(14 \%)$ \\
\hline hypo HDL-c & $210(15 \%)$ & $107(18 \%)$ & $103(12 \%)$ \\
\hline hyper TG & $470(33 \%)$ & $163(27 \%)$ & $307(37 \%)$ \\
\hline
\end{tabular}

Lipid profile was assessed in the studied hypertensive patients. Dyslipidemias were very common (54\%). Hyper-TC and hyper-TG were the main dyslipidemias. The prevalence of dyslipidemias was higher among women.

Table 3 Fasting blood glucose levels of the hypertensive patients

\begin{tabular}{|llll|}
\hline & Total & Men & Women \\
\hline $\mathrm{N}$ & 1395 & 587 & 808 \\
$\mathrm{FBGI}$ & $6.03 \pm 1.63$ & $6.01 \pm 1.70$ & $6.04 \pm 1.58$ \\
(m \pm SD,mmol/L) & & & \\
\hline $\begin{array}{l}\text { Patients with abnormal } \\
\text { glucose metabolism(N, \%) }\end{array}$ & $517(37 \%)$ & $209(36 \%)$ & $308(38 \%)$ \\
\hline By FBG & & & \\
\hline $6.1-7$ & $294(21 \%)$ & $112(19 \%)$ & $182(22 \%)$ \\
$\geq 7$ & $223(16 \%)$ & $97(17 \%)$ & $126(16 \%)$ \\
\hline
\end{tabular}

FBG: fasting blood glucose level 
The abnormal glucose metabolism ( $F B G \geq 6.1 \mathrm{mmol} / \mathrm{L}$ ) was common. It's prevalence was $37 \%$. In addition, $16 \%$ of the population had hyperglycemia ( $F B G \geq 7.0 \mathrm{mmol} / \mathrm{L}$ ).

Table 4 Diet of the studied hypertensive population 


\begin{tabular}{|c|c|c|c|}
\hline Food category & Intake & Percent & Recommendation* \\
\hline \multirow[t]{4}{*}{ Carbohydrates \# } & & & $250-400 \mathrm{~g} / \mathrm{d}$ \\
\hline & $<250 \mathrm{~g} / \mathrm{d}$ & $35.88 \%$ & \\
\hline & $250-500 \mathrm{~g} / \mathrm{d}$ & $47.33 \%$ & \\
\hline & $>500 \mathrm{~g} / \mathrm{d}$ & $16.79 \%$ & \\
\hline \multirow[t]{3}{*}{ Meat } & & & $50-75 \mathrm{~g} / \mathrm{d}$ \\
\hline & $<50 \mathrm{~g} / \mathrm{d}$ & $82.20 \%$ & \\
\hline & $\geq 50 \mathrm{~g} / \mathrm{d}$ & $17.80 \%$ & \\
\hline \multirow[t]{3}{*}{ Vegetables } & & & $300-500 \mathrm{~g} / \mathrm{d}$ \\
\hline & $<300 \mathrm{~g} / \mathrm{d}$ & $59.01 \%$ & \\
\hline & $\geq 300 \mathrm{~g} / \mathrm{d}$ & $40.99 \%$ & \\
\hline \multirow[t]{4}{*}{ Fruits } & & & $200-350 \mathrm{~g} / \mathrm{d}$ \\
\hline & $<100 \mathrm{~g} / \mathrm{d}$ & $63.40 \%$ & \\
\hline & $100-200 \mathrm{~g} / \mathrm{d}$ & $33.86 \%$ & \\
\hline & $>200 \mathrm{~g} / \mathrm{d}$ & $2.74 \%$ & \\
\hline \multirow[t]{3}{*}{ Eggs } & & & $280-350 \mathrm{~g} / \mathrm{w}$ \\
\hline & $<280 \mathrm{~g} / \mathrm{w}$ & $83.50 \%$ & \\
\hline & $\geq 280 \mathrm{~g} / \mathrm{w}$ & $16.50 \%$ & \\
\hline \multirow[t]{4}{*}{ Oil \# } & & & $750-900 \mathrm{~g} / \mathrm{m}$ \\
\hline & $<500 \mathrm{~g} / \mathrm{m}$ & $49.35 \%$ & \\
\hline & $500-1000 \mathrm{~g} / \mathrm{m}$ & $40.27 \%$ & \\
\hline & $>1000 \mathrm{~g} / \mathrm{m}$ & $10.38 \%$ & \\
\hline \multirow[t]{3}{*}{ Salt } & & & $6 \mathrm{~g} / \mathrm{d}$ \\
\hline & $\leq 360 \mathrm{~g} / \mathrm{m}$ & $1.30 \%$ & \\
\hline & $>360 / \mathrm{m}$ & $98.70 \%$ & \\
\hline average & $23.5 \pm 17.3 \mathrm{~g} / \mathrm{d}$ & & \\
\hline \multicolumn{4}{|c|}{ Salty pickles such as pickles, soy sauce } \\
\hline & yes & $75.65 \%$ & \\
\hline & no & $24.35 \%$ & \\
\hline
\end{tabular}


$\mathrm{N}=1388$. Recommendation*: intake recommended by China's dietary guidelines $₫ 2016 \rrbracket$

\#: The residents are used to weighing by $\mathrm{Jin}$. $1 \mathrm{Jin}=500 \mathrm{~g}$. Therefore, in order to be easy to estimation, $250 \mathrm{~g}, 500 \mathrm{~g}$ and $1000 \mathrm{~g}$ were used in the questionnaire to measure the intake of carbohydrates and oil.

The diet was very unbalanced despite of low fat intake. Seriously insufficient intake of protein『meat, egg $₫$, vegetables and fruits while salt intake was too much.

\section{Figures}
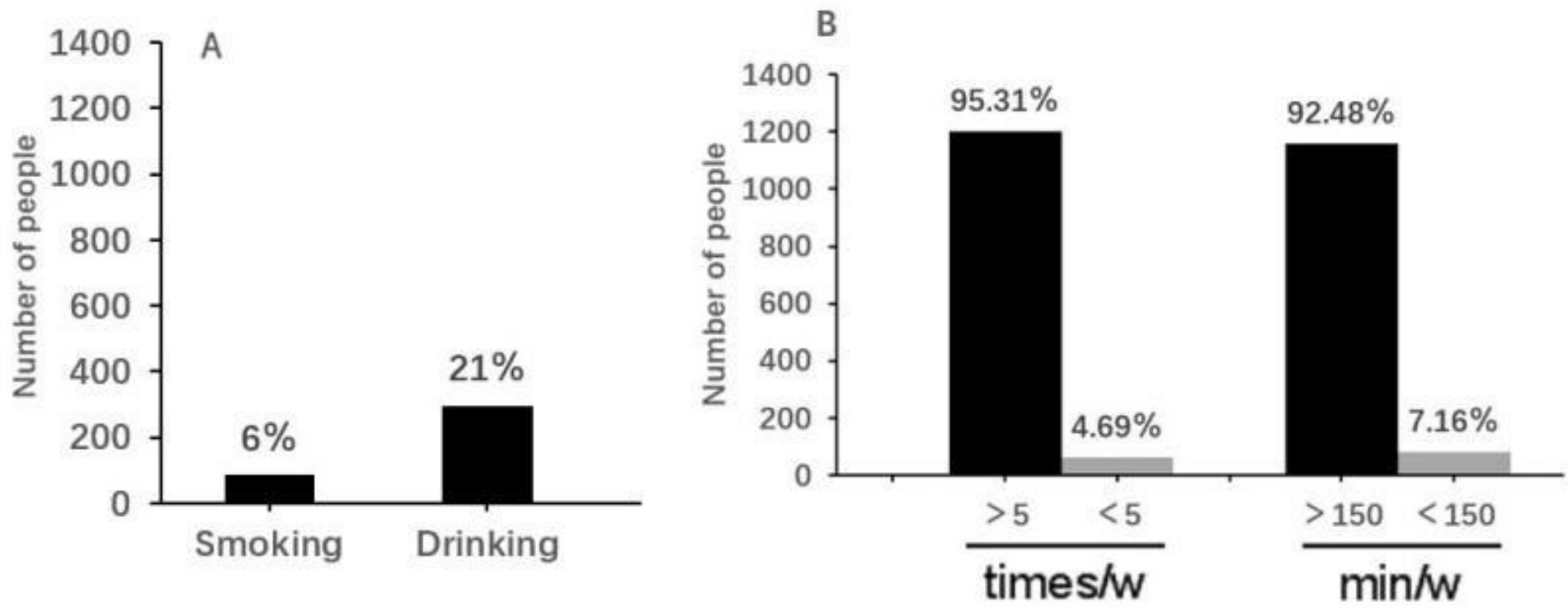

Figure 1

Health habit of the studied hypertensive population $N=1388$. A: There were few patients with drinking, and only a small number of the patients with smoking (21.47\%). B: Most of the patients had enough physical activity ( $\geq 5$ times/week, $95.31 \%$; $\geq 150 \mathrm{~min} /$ week, $92.84 \%$ ). 